\title{
Assessment of a DNA vaccine encoding an anchored- glycosylphosphatidylinositol tegumental antigen complexed to protamine sulphate on immunoprotection against murine schistosomiasis
}

\author{
Eduardo JM Nascimento, Rosa V Amorim*, André Cavalcanti, Veruska F Alves, \\ Mineo Nakazawa, Valéria RA Pereira, Norma Lucena-Silva/ ${ }^{+}$
}

\author{
Centro de Pesquisas Aggeu Magalhães-Fiocruz, Av. Moraes Rego, s/nº, Cidade Universitária, 50670-420 Recife, PE, Brasil \\ *Departamento de Biologia Molecular, Universidade Federal da Paraíba, João Pessoa, PB, Brasil
}

Protamine sulphate/DNA complexes have been shown to protect DNA from DNase digestion in a lipid system for gene transfer. A DNA-based vaccine complexed to protamine sulphate was used to induce an immune response against Schistosoma mansoni anchored-glycosylphosphatidylinositol tegumental antigen in BALB/c mice. The protection elicited ranged from 33 to $44 \%$. The spectrum of the elicited immune response induced by the vaccine formulation without protamine was characterized by a high level of $\operatorname{Ig} G\left(\operatorname{Ig} G_{1}>\operatorname{Ig} G_{2 \alpha}\right)$. Protamine sulphate added to the DNA vaccine formulation retained the green fluorescent protein encoding-plasmid longer in muscle and spleen. The experiments in vivo showed that under protamine sulphate effect, the scope of protection remained unchanged, but a modulation in antibody production $\left(\operatorname{Ig} G_{1}=\operatorname{Ig} G_{2 a}\right)$ was observed.

Key words: DNA vaccines - pECL - protamine sulphate - schistosomiasis

DNA vaccines have been considered potential immunization tools against schistosomiasis (Pearce 2003, McManus 2005, Bergquist et al. 2005). In recent years, considerable effort has been made to develop a protective vaccine against schistosome infection and several potential DNA constructs encoding several candidate molecules have been identified (Yang et al. 1995, Waine et al. 1999, Hota-Mitchell et al. 1999, Da'dara et al. 2002a,b, Nascimento et al. 2002, Sidiqui et al. 2003a,b, Shalaby et al. 2003, Fonseca et al. 2006, Zhu et al. 2006).

Schistosome tegumental antigens have been shown to play a pivotal role on the evasive mechanisms of Schistosoma mansoni in a mammalian host. Host proteins often hide these antigens, but after praziquantel treatment several of these antigens were exposed, including the glycosylphosphatidylinositol (GPI)-anchored $200 \mathrm{kDa}$ protein, termed ECL, present in every stage of the worm's life. Such an effect has been regarded essential for the host immunity-dependent effect of praziquantel (Brindley et al. 1989). Nevertheless, even without PQZ exposition, the adult worm still exposes the GPI-anchored 200kDa protein on its surface, although in a smaller proportion; 5-fold less than with PQZ exposition (Sauma et al. 1991). Thus, the possibility of using ECL as an immunogen to trigger the immune response against $S$. mansoni alone or in association with current

Financial support: PADCTIII/CNPq No. 620470/98-4, Pibic/Fiocruz

${ }^{+}$Corresponding author: nlucena@cpqam.fiocruz.br

Received 18 May 2006

Accepted 29 November 2006 chemotherapy for effective schistosomiasis control has been suggested (Brindley et al. 1989).

In the present study, the immune and protective response against $S$. mansoni infection in a murine model induced by immunization with ECL-encoded plasmid DNA complexed with protamine sulphate was evaluated. Protamine sulphate is a major component of the sperm nucleus and is involved in packaging sperm DNA to improve its stabilization. It has been shown that nucleic acid presents an electrostatic interaction with protamine sulphate, forming a particle whose role might be to protect DNA from deoxyendonuclease attack (Gao \& Huang 1996, Sorgi et al. 1997, Li et al. 1999, You et al. 1999, Dokka et al. 2000, Welz et al. 2000). Moreover, protamine sulphate is available worldwide at low cost, and has been safely administrated for more than fifty years (FDA approval 1951, UpJohn Pharmaceuticals, Kalamazoo, MI, US) to reverse the effects of heparin, as well as to slow down the release of insulin in premixes used for the treatment of both type-1 and type-2 diabetes mellitus (Lanuti et al. 1999, Jacobsen et al. 2000). These characteristics make protamine sulphate a possible adjuvant for use with a DNA vaccine.

\section{MATERIALS AND METHODS}

Animals - Female BALB/c mice (6 weeks old) were raised at the animal facilities of the Oswaldo Cruz Foundation (Fiocruz, Rio de Janeiro, Brazil). The guidelines of the Ethical Committee for the use of experimental animals of the Fiocruz were followed.

Plasmid constructs and production - The pGFP construct contains a CMV promoter, a polyadenylation site and adeno-associated virus (AAV) inverted terminal-repeats (ITR) flanking the expression elements. pECL was constructed from three fragments of the $200 \mathrm{kDa}$ an- 
chored glycosylphosphatidylinositol tegumental protein of $S$. mansoni, linked in frame, and inserted into the pVAX1 vector (Invitrogen, Germany). Escherichia coli DH5- $\alpha$ strains harboring each plasmid were grown overnight in Luria-Bertani liquid media supplement with 70 $\mu \mathrm{g} / \mathrm{ml}$ of kanamycin sulfate (USB, Cleveland, US). Plasmid DNA was extracted and purified using the Concert High Purity Plasmid Purification Systems (GibcoBRL, Germany) and sterilized with $70 \%$ ethanol wash.

Protamine sulphate DNA complexation - Several ratios (weight/weight) of protamine sulphate (Sigma, St. Louis, US) and pECL plasmid DNA were tested. Protamine sulphate was added to $1 \mu \mathrm{g}$ of pECL plasmid in the following ratios: $0.2,0.4,0.6,0.8$, and $1(\mathrm{w} / \mathrm{w})$. Each Protamine-DNA ratio was tested for its capacity to protect the plasmid against digestion with DNase I (GibcoBRL, Germany). Aliquots of insoluble complexes of protamine-DNA were exposed to DNase I (0.05 unit/ $\mu \mathrm{l}$ ) for $15 \mathrm{~min}$ at $37^{\circ} \mathrm{C}$. Finally, protamine degradation was performed, in order to release the wrapped DNA, by adding Proteinase K (Invitrogen, Germany) for $10 \mathrm{~min}$ at $68^{\circ} \mathrm{C}$. Samples from each step were analyzed by electrophoresis on a $1 \%$ agarose gel.

Kinetic expression of plasmid-encoded protein in vivo - Three mice were injected with $50 \mu \mathrm{g}$ of pGFP intramuscularly with and without the presence of protamine sulphate [protamine sulphate/DNA weight ratio 0.6 $(\mathrm{w} / \mathrm{w})]$. The experiment was set up so that the mice of different groups could be sacrificed and the tissues (muscle and spleen) sliced on the same day. A green fluorescent protein produced in vivo was analyzed under fluorescence microscopy on 5 to 10 slices of each tissue processed. Kinetic expression of GFP was analyzed on days $1,3,7$, and 28 after the inoculation of either pGFP complexed or not with protamine sulphate. The control group was injected with saline. Slices were classified as positive or negative according to the presence or absence of pGFP-expressing tissues, respectively.

Immunization experiments - Subcutaneous or intramuscular immunization was carried out using a $1 \mathrm{ml}$ syringe fitted with a 27 -gauge needle at a total injection volume of $50 \mu 1$. In Experiment 1, experimental groups of six mice were immunized with two doses of 2.5 or 25 $\mu \mathrm{g}$ of $\mathrm{pECL} / \mathrm{mouse}$ at two week interval. Another two groups were immunized in parallel with 2.5 or $25 \mu \mathrm{g}$ of unspecific DNA (empty pVAX1). Blood samples were collected after priming and boost for humoral immune response analyzes. Experiment 2 was designed to test the effect of co-administrating protamine sulphate on vaccine efficacy (immunoprotection). The protocol followed in this experiment was similar to that just described for experiment 1 except that challenge and perfusion were included.

Challenge and worm load determination - One week after the boost, the mice were challenged with $80 \mathrm{~S}$. mansoni cercariae SLM (São Lourenço da Mata, a regional strain) percutaneously. Six weeks after challenge, the portal vein of infected mice was perfused with sa- line for worm harvesting and load determination. The protection level was calculated as a percentage of the worm burden observed in the experimental group in relation to the control group.

ELISA for antibody-mediated response analysis Serum samples were collected from each mouse by retro orbital bleeding before each immunization and challenge with cercariae. Soluble egg antigen (SEA) was obtained according to a methodology described elsewhere (Pearce et al. 1991). Ninety-six-well micro titer plates (Nunc, Denmark) were coated overnight at $4^{\circ} \mathrm{C}$ with SEA $(10 \mathrm{ng} / \mu \mathrm{l})$, washed with PBS containing $0.05 \%$ Tween 20 (PBS/Tw20) and blocked for $3 \mathrm{~h}$ with a solution containing 2\% BSA (USB, Cleveland, US) in PBS/Tw20. The mice pooled sera were then diluted 1:50 in PBS/Tw20. After incubation overnight at $4^{\circ} \mathrm{C}$, the plates were washed six times with PBS/Tw20 and incubated for $1 \mathrm{~h}$ at room temperature with a $1 / 1000$ dilution of either a peroxidase-conjugated with goat anti-mouse Ig polyclonal or biotin-conjugated goat anti-mouse $\operatorname{Ig}\left(\mathrm{IgG}_{1}, \mathrm{IgG}_{2 \mathrm{a}}, \mathrm{IgG}_{3}\right.$ and IgE) $(0.5 \mu \mathrm{g} / \mathrm{ml})$ (Pharmigen). The plates containing the biotin-conjugated antibodies were washed six times with PBS/Tw20 and incubated for $1 \mathrm{~h}$ at room temperature with a $1 / 1,000$ dilution of a peroxidase-conjugated streptavidin (Pharmigen, San Diego, CA, US). The plates were then washed and the reaction developed with ABTS for $30 \mathrm{~min}$ at room temperature and analyzed at $415 \mathrm{~nm}$ in an ELISA Reader model 3550 (BioRad, Richmond, US).

Statistic analysis - The variance of the worm burden between the control group and each sample group was first calculated by the F-Test and then submitted to the Student Test. All calculations were made using Excel software (Microsoft, CA, US). The protection was considered significant when $\mathrm{p}<0.05$.

\section{RESULTS}

Protamine protection on plasmid degradation - The binding of protamine to the DNA molecule shifts DNA migration. The reduced rate of DNA migration is dependent on protamine sulphate/DNA weight ratios and was completely abolished at a ratio of 0.8 (Fig. 1A). When each protamine DNA weigh ratio was exposed to DNAse I digestion there was apparently free-DNA degradation, since the bands disappeared in gel at ratios of $0.2,0.4$, and 0.6 (Fig. 1B). These findings suggest that a small percentage of free-DNA that is susceptible to degradation remained in all vaccine formulations independent of the protamine/DNA weight ratios used. After protamine digestion and DNA releasing, intact plasmid DNA was observed in the vaccine formulation that used the protamine weight at ratios of 0.6 to 1 (Fig. 1C), confirming the role of protamine in DNA protection against nuclease attack. Based on these results, we decided to use the protamine/DNA weight ratio of 0.6 for further immunization studies.

Kinetics of the expression of plasmid DNA in the host tissue - The group of mice injected with naked pGFP, showed pGFP-expressing cells on day 1,3 , and 7 , but 


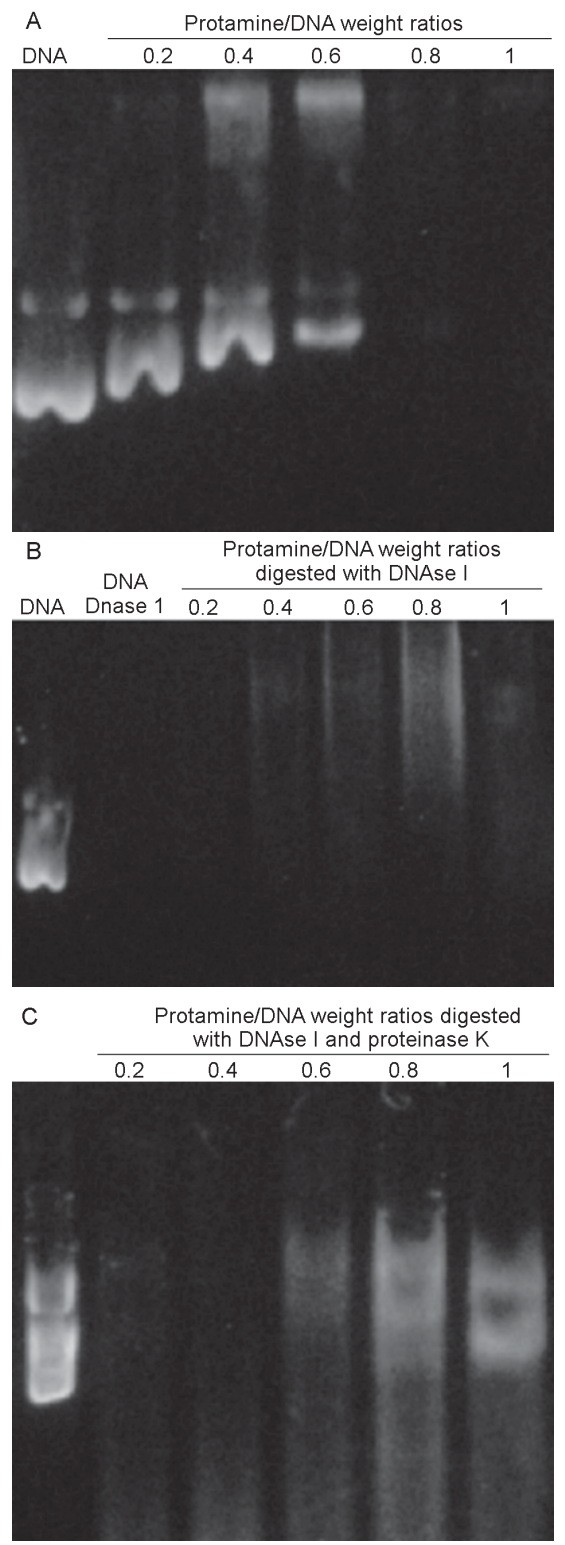

Fig. 1: analysis of $\mathrm{pECL} /$ protamine sulphate complexes and evaluation of physical stability from nuclease digestion. A: different amounts of protamine sulphate were complexed with $1 \mu \mathrm{g}$ of $\mathrm{pECL}$. The weight ratio of protamine sulphate/pECL ranged from 0.2 to 1 ; $\mathrm{B}$ : the complexes were submitted to DNase I digestion and the product of DNAse digestion was treated with proteinase $\mathrm{K} ; \mathrm{C}$ : to release the wrapped DNA.

not on day 28 after injection, as shown in Table I. In the spleen, the fluorescence was only observed 7 days after injection. However, the group that was injected with protamine sulphate added to the pGFP formulation showed pGFP-expressing tissue throughout the experiment. Furthermore, it appeared that in the spleen there were fluorescent cells from the 3 rd to the 28th day. In the control group there were no tissues showing pGFP expression at any point of assessment (data not shown).

Assessment of humoral immune response elicited by $p E C L$ - SEA-specific Ig elicited by $\mathrm{pECL}$ was dose-
TABLE I

Kinetics of GFP expression in muscle and spleen after mice immunization with pGFP alone or complexed with protamine sulphate

\begin{tabular}{lcccc}
\hline & \multicolumn{5}{c}{ Naked pGFP } \\
\cline { 2 - 5 } Tissue & Day 1 & Day 3 & Day 7 & Day 28 \\
\hline Muscle & + & + & + & - \\
Spleen & - & - & + & - \\
\hline & \multicolumn{4}{c}{ pGFP/Protamine sulphate complex } \\
\cline { 2 - 5 } & Day 1 & Day 3 & Day 7 & Day 28 \\
\hline Muscle & + & + & + & + \\
Spleen & - & + & + & + \\
\hline
\end{tabular}

dependent for both routes tested, but with higher levels when the intramuscular route was used (Fig. 2A). The same pattern was observed for both $\operatorname{IgG}_{1}$ and $\operatorname{IgG}_{2 \mathrm{a}}$ (Figs $2 \mathrm{~B}$, and $2 \mathrm{C}$ respectively). $\operatorname{IgG}_{3}$ and $\mathrm{IgE}$ were not detected in these samples (data not shown). In contrast, saline and unspecific vector (empty pVAX1) did not elicit measurable antibody levels.

Analyses of the humoral immune response to naked $p E C L$ and the protamine/pECL complex - As shown in Fig. 3, the addition of protamine sulphate to the $\mathrm{pECL}$ formulation seemed to delay the serum-conversion of total immunoglobulin, since the levels of these antibodies after the first and second doses were lower than those produced after naked $\mathrm{pECL}$ immunization. In relation to the $\mathrm{IgG}$ isotypes in a pool of sera harvested after the boost, there was a decrease in $\mathrm{IgG}_{1}$ levels influenced by protamine in the $\mathrm{pECL}$ formulation, and similar levels of $\mathrm{IgG}_{2 \mathrm{a}}$ elicited by both naked and protamine entrapped DNA (Fig. 4). However, no $\mathrm{IgG}_{3}$ and $\mathrm{IgE}$ were detected (data not shown).

Analyses of the protective immunity elicited by naked pECL and the protamine/pECL complex - The mean worm burden obtained in the saline, protamine sulphate, $\mathrm{pECL}$ and protamine sulphate/pECL groups was 17.5, 14.5, 10.8, and 11.0 respectively (Table II). According to these results, the protection induced by $\mathrm{pECL}$, regardless of the presence of protamine sulphate, was statistically similar (37.1\%, Protamine $/ \mathrm{pECL}$ and $38.1 \%$, pECL, $p>0.05)$ and both were significant $(p<0.05)$ in relation to control group saline.

\section{DISCUSSION}

Protamine sulphate was showed to protect the DNA vaccine from in vitro and in vivo degradation. As adjuvant, protamine sulphate did not improve the worm burden reduction of $37 \%$ obtained with $25 \mu \mathrm{g}$ of a naked DNA vaccine based on the tegumental glycosylphosphatidylinositol (GPI)-anchored 200kDa encoded sequence ( $\mathrm{pECL}$ ), but it did induce a changing in antibody profile.

Previous reports demonstrated that protamine/DNA complexes protect DNA from DNase digestion in a lipid 

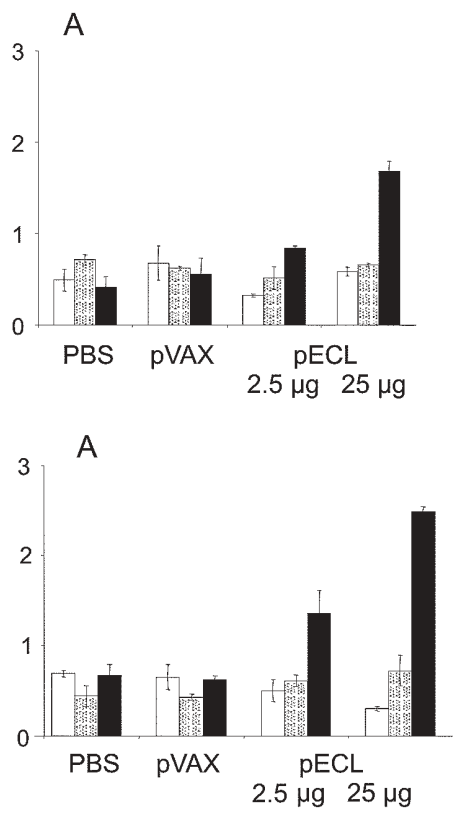

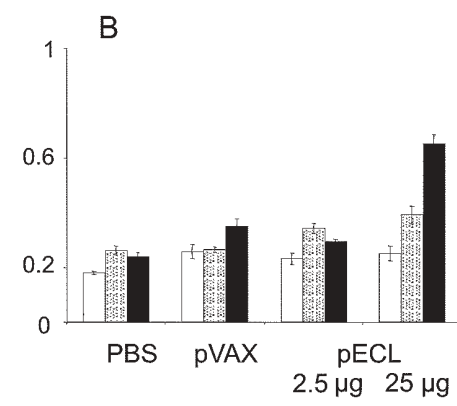

B

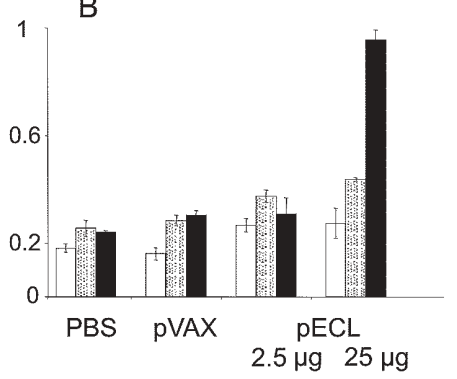

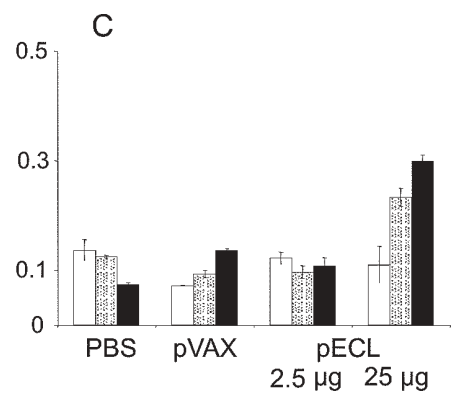

C

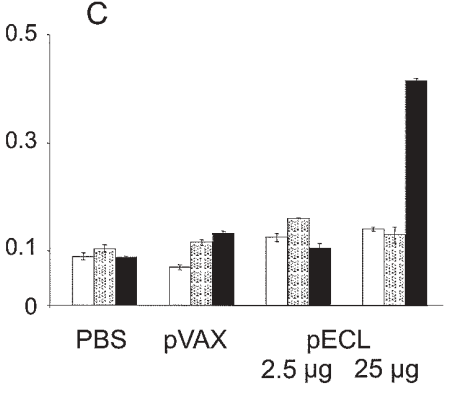

$\square$ Pre Immune $\quad$ After Priming $\square$ After Boosting

Fig. 2: antibody levels of total anti-SEA Ig polyclonal (A), IgG1 (B), and IgG2a (C) in subcutaneously (top panel) or intramuscularly (bottom panel) $\mathrm{pECL}$-immunized mice. ELISA was performed using a pool of sera of each group analyzed (1:50 dilution).

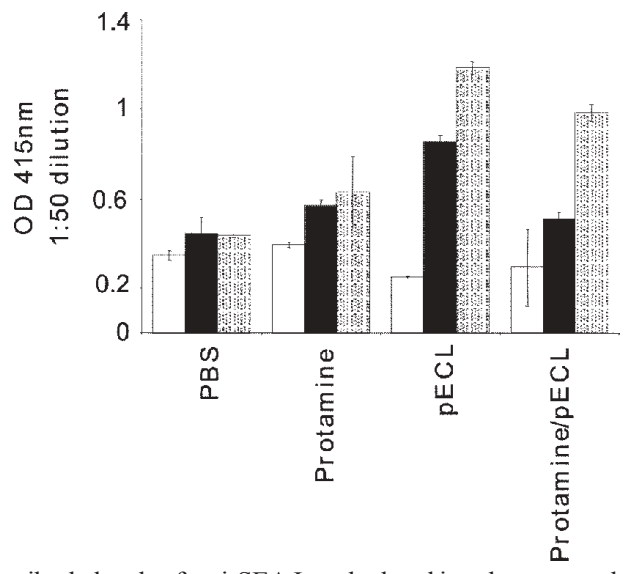

Fig. 3: antibody levels of anti-SEA Ig polyclonal in subcutaneously pECL/ protamine sulphate-immunized mice. ELISA was performed using a pool of sera of each group analyzed.

system for gene transfer (You et al. 1999). In the present paper, protamine sulphate complexed to a DNA-encoding plasmid was employed in an aqueous environment, instead of in liposomes. In this system, we were able to demonstrate that, even without liposomes, protamine sulphate was able to partially protect the DNA from nuclease attack in vitro with higher weight ratios of protamine/DNA [0.6, 0.8, and $1(\mathrm{w} / \mathrm{w})]$. It is likely that the DNA was only partially protected by protamine due to
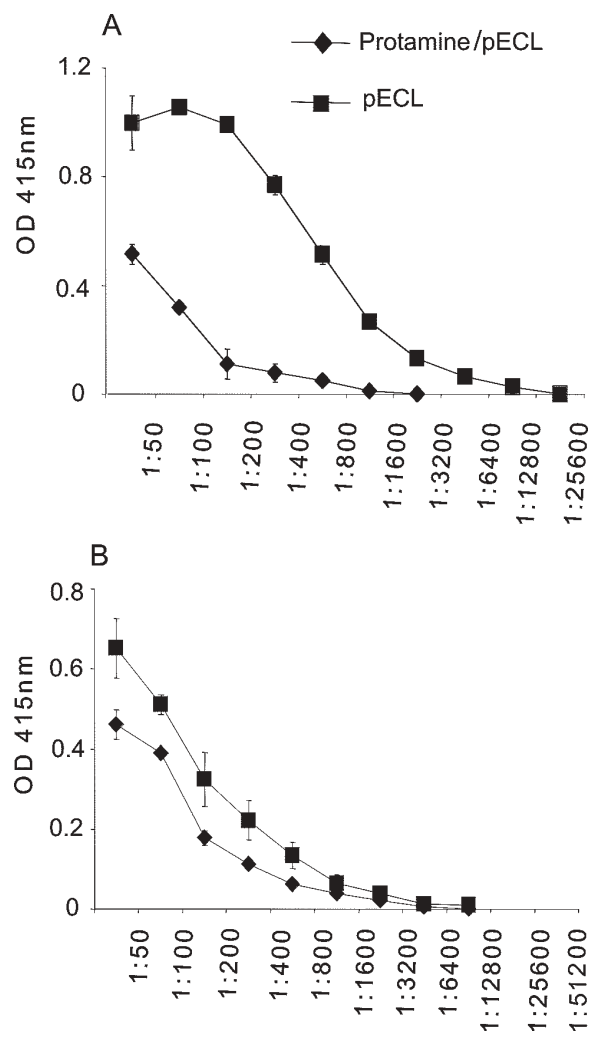

Fig. 4: titers of anti-SEA IgG subtype antibodies in $\mathrm{pECL}$ or $\mathrm{pECL} /$ protamine sulphate subcutaneously immunized mice. IgG1 (A) and IgG2a (B). 
TABLE II

Adult worm burdens of mice vaccinated with $\mathrm{pECL} /$ protamine sulphate complexes subcutaneously

\begin{tabular}{|c|c|c|c|c|}
\hline $\begin{array}{l}\text { Groups } \\
\text { (n) }\end{array}$ & $\begin{array}{l}\text { Worm burden } \\
(\text { mean } \pm \mathrm{sd})\end{array}$ & $\begin{array}{c}\text { Protection } \\
(\%)\end{array}$ & $\begin{array}{c}\text { T-test } \\
\text { value }(\mathrm{p}) a\end{array}$ & $\begin{array}{c}\text { T-test } \\
\text { value }(\mathrm{p})^{b}\end{array}$ \\
\hline Saline (6) & $17.50( \pm 3.73)$ & - & - & - \\
\hline $2 \times 15 \mu$ g protamine $(6)$ & $14.50( \pm 1.52)$ & 17.14 & 0.11 & - \\
\hline $2 \times 25 \mu \mathrm{g} \mathrm{pECL}(6)$ & $10.83( \pm 3.66)$ & 38.10 & 0.01 & - \\
\hline $2 \times 25 \mu \mathrm{g}$ pECL $+1 \mu \mathrm{g}$ protamine $(6)$ & $11.00( \pm 5.57)$ & 37.14 & 0.04 & 0.17 \\
\hline
\end{tabular}

$a$ : analysis realized in relation to the saline control group; $b$ : analysis realized in relation to the pECL group.

its availability on the carrier's surface. It is interesting to note that an increase in the weight ratio of protamine/ DNA leads to a reduced rate of the protamine/DNA complex migration on agarose gel until it is entirely abolished. This is most likely due to both the charge neutralization of the DNA and the increased size of the protamine/DNA complex (Dokka et al. 2000). When protamine sulphate was added to DNA, it formed a cloud-like structure at room temperature, 37 and $42^{\circ} \mathrm{C}$ (data not shown), which makes it technically difficult to use the protamine/DNA complex. Vigorous homogenization might break the complex into small fragments that could be administrated through an insulin syringe. Protamine sulphate seemed to protect the DNA structure during the physical shock (data not shown). Birchall and colleagues showed that even after nebulization (high pressure), the presence of protamine sulphate allowed for physical stability of the nucleic acid, confirming the protamine feature of protecting DNA from physical breaks (Birchall et al. 2000). The results presented here showed also that protamine sulphate improves pGFP transfection into the muscle cells, either by increasing the number of transfected cells or by protecting the plasmid DNA from cellular nuclease digestion, ensuring that the plasmid was available in the cell for a longer period.

In a previous report, our group showed worm burden reduction rates between $45-65 \%$. The best protection level was achieved with a cocktail of anti-schistosome DNA vaccines containing $\mathrm{pECL}$ and two other DNA vaccines, pIrV5 and pSm14, which code for a muscular and a tegumental schistosome-antigen, respectively (Nascimento et al. 2002). Variable protection levels have been obtained with mice vaccinated with different DNA constructs. Worm burden reduction ranging between 25 $42 \%$ has been reported as result of immunization with S. mansoni Sm23-pcDNA and pCI/Sm14 (Da'dara et al. 2002a,b, Fonseca et al. 2006); while immunization with DNA encoding a large subunit of calpain (p80) protease of $S$. mansoni registered a protection range between 2960\% (Hota-Mitchell et al. 1999, Siddiqui et al. 2003a,b). The main goal for worm vaccine strategy has been to decide what antigens to use based on induced protection levels as the levels vary with the antigen considered and between experiments. A vaccination protocol tested in $\mathrm{C} 57 \mathrm{Bl} / 6$ mice with different antigen-encoding DNA vaccines showed a protection of 44 to $60 \%$ for a $\mathrm{Cu} / \mathrm{Zn}$ cytosolic super oxide dismutase [SOD]-DNA construct;
22 to $45 \%$ for a signal peptide-containing SOD-DNA construct; 23 to $55 \%$ for a wild type glutathione peroxidase-DNA construct; 25 to $34 \%$ for a mutated glutathione peroxidase-DNA construct and $85 \%$ when priming with DNA vaccine followed by a boost of a recombinant vaccinia virus-bearing glutathione peroxidase construct (Shalaby et al. 2003). Some authors have also reported a lack of either antibody production or worm burden reduction elicited by some DNA vaccines against schistosomiasis in different animal models (Yang et al. 1995, Waine et al. 1999).

The humoral immune response has been regarded as an important mechanism of resistance against $S$. mansoni (Jankovic et al. 1999). The magnitude and quality of the humoral immune response elicited depends on the route and dose used (Cohen et al. 1998, Raviprakash et al. 2000). In the present study, intramuscular and subcutaneous routes for pECL immunization were assessed. The subcutaneous route was analyzed, as the skin is the entry door for infection establishment by schistosome (Hota-Mitchell et al. 1999). In addition, the existence of a larger number of immature antigen-presenting cells, such as Langerhans cells, in the epidermis and the possibility of homing effectors cells to the immunization site also contributed to the choice of using this route for DNA immunization (Robinson 1999, Eberl et al. 2001). pECL was able to stimulate $\operatorname{IgG}_{1}$ and $\mathrm{IgG}_{2 \mathrm{a}}$ $\left(\mathrm{IgG}_{1}>\mathrm{IgG}_{2 \mathrm{a}}\right)$ in a dose-dependent manner for both routes used. Regardless of the route used, pECL elicited the same profile of humoral immune response. However, the intramuscular route elicited higher levels of both IgG isotypes than the subcutaneous route. These results are in disagreement with that described by Da'dara and colleagues. Their work reported that the humoral immune response elicited by another tegumental schistosome antigen-DNA construction, Sm23pcDNA, varied according to the route used. They observed a predominant production of $\mathrm{IgG}_{2 \mathrm{a}}$ when the intramuscular route was used, whereas $\operatorname{IgG}_{1}$ was predominant in mice inoculated by intradermal route (Da'dara et al. $2002 \mathrm{a}, \mathrm{b}) . \operatorname{IgG}_{3}$ and $\operatorname{IgE}$ were not detected in the collected samples. Some works have reported variable levels of IgG3 elicited, but not IgE (Da'dara et al. 2002b, Siddiqui et al. 2003a).

The modulation of the immunity elicited by pECL in the presence of protamine sulphate was also assessed. The humoral immune response analyzes showed that na- 
ked pECL, through a subcutaneous route, predominantly elicited antigen-specific $\operatorname{IgG}_{1}(1: 6400)$. However, the addition of protamine to the DNA formulation partially abolished this effect, with a balanced titer of $\mathrm{IgG}_{1}$ and $\operatorname{IgG}_{2 \mathrm{a}}(1: 3200$ each). It is most likely that the diminished level of total immunoglobulin in response to $\mathrm{pECL} /$ protamine, compared to naked $\mathrm{pECL}$, was due to the diminished titer of $\operatorname{IgG}_{1}$ shown in this group. Nevertheless, this difference in the humoral profile does not influence immune protection data, since both $\mathrm{pECL}$ and $\mathrm{pECL} /$ protamine formulation induced similar worm burden reduction. $\mathrm{IgG}_{3}$ and IgE were not detected after pECL immunization. Hota-Mitchell and colleagues also demonstrated anti-MUT p80 antibodies $\operatorname{IgG}_{1}$ and $\operatorname{IgG}_{2 \mathrm{a}}$, but not $\mathrm{IgG}_{3}$ and $\mathrm{IgE}$ induced by three immunizations (intradermal route) with a DNA expressing a mutated large subunit of calpain (p80) protease. According to the authors, $\mathrm{IgG}_{1}$ polarized response resulted in the protection in mice, whereas the balanced levels of $\operatorname{IgG}_{1}$ and $\operatorname{IgG}_{2 \mathrm{a}}$ failed to provide protection in mice (Hota-Mitchell et al. 1999). In contrast, the present results suggest that either $\mathrm{IgG}_{1}$ or $\mathrm{IgG}_{2 \mathrm{a}}$ might be important for protection against schistosomiasis.

Vaccine formulations based on novel adjuvant could improve the final outcome through selective manipulation of the immune response (Bergquist et al. 2005). The strategy commonly used to increase the immune response induced by antigen-encoded DNA vaccines is to add in the vaccine formulation cytokines-encoded plasmids. The genetic adjuvant IL-12 has been showed to increase splenocyte proliferation and protection in mice vaccinated with the large subunit of calpain (Siddiqui et al. 2005). However, the use of IL-12 as a genetic adjuvant to Sm14 DNA vaccine failed to enhancer protection against challenge infection in mice (Fonseca et al. 2006). Triose-phosphate isomerase (TPI) plasmid DNA vaccine in conjunction with IL-12 encoded plasmid incubated in naive pigs did not also improve reduction in adult worm burden, but showed more pronounced effect on worm egg output and simultaneously hepatic egg-associated pathology (Zhu et al. 2006).

The results of the present work suggested that $\mathrm{pECL}$ vaccination is capable of protecting $\mathrm{BALB} / \mathrm{c}$ mice against experimental schistosomiasis. In addition, protamine sulphate as a DNA vaccine carrier protects the vaccine against cellular nuclease digestion allowing the vaccineencoding plasmid to be expressed longer in the muscle and spleen. Moreover, studies in vivo showed that despite the different antibody profile elicited by protamine/ pECL, the scope of protection did not change. Further studies are ongoing to identify the GFP-expressing cells in situ as well as their influence on the cellular immune response elicited. We believe that this is a promising formulation for DNA vaccines in general, thus it would be interesting to test further this formulation using a multi antigen-DNA vaccine.

\section{ACKNOWLEDGMENTS}

To Dr Ernesto Marques Jr., The Johns Hopkins University, for kindly donating the pECL, pGFP plasmids, and protamine sulphate for the in vivo studies of protection. To Roni Venâncio for his help with the microtomy, and to Conceição Maria and Maria Inês for taking excellent care of the mice.

\section{REFERENCES}

Bergquist NR, Leonardo LR, Mitchell GF 2005. Vaccine-linked chemotherapy: can schistosomiasis control benefit from an integrated approach? Trends Parasitol 21: 112-117.

Birchall JC, Kellaway IW, Gumbleton M 2000. Physical stability and in-vitro gene expression efficiency of nebulised lipid-peptide-DNA complexes. Int J Pharm 197: 221-231.

Brindley PJ, Strand M, Nordrem AP, Sher A 1989. Role of host antibody in the chemotherapeutic action of praziquantel against Schistosoma mansoni: identification of target antigens. Mol Biochem Parasitol 34: 99-108.

Cohen AD, Boyer JD, Weiner DB 1998. Modulating the immune response to genetic immunization. FASEB 12: 1611-1626.

Da'dara AA, Skelly PJ, Wang M, Harn DA 2002a. Immunization with plasmid DNA encoding the integral membrane protein, $\mathrm{Sm} 23$, elicits a protective immune response against schistosome infection in mice. Vaccine 20: 359-369.

Da'dara AA, Skelly PJ, Fatakdawala M, Visovatti S, Eriksson E, Harn DA 2002b. Comparative efficacy of the Schistosoma mansoni nucleic acid vaccine, Sm23, following micro seeding or gene gun delivery. Parasite Immunol 24: 179-187.

Dokka S, Toledo D, Shi X, Ye J, Rojanasakul Y 2000. High-efficiency gene transfection of macrophages by lipoplex. Int J Pharm 206: 97-104.

Eberl M, Langermans JAM, Frost PA, Vervenne RA, Dam GJV, Deelder AM, Thomas AW, Coulson OS, Wilson A 2001. Cellular and humoral immune responses and protection against schistosomes induced by a radiation-attenuated vaccine in chimpanzees. Infect Immun 69: 5352-5362.

Fonseca CT, Pacifico LG, Barsante MM, Rassi T, Cassal GD, Oliveira SC 2006. Co-administration of plasmid expressing IL-12 with 14-kDa Schistosoma mansoni fatty acid-binding protein cDNA alters immune response profiles and fails to enhance protection induced by Sm14 DNA vaccine alone. Microbes Infect Jul 24: [Epub ahead of print].

Gao X, Huang L 1996. Potentiation of cationic liposome-mediated gene delivery by polycations. Biochemistry 35: 1027 1036.

Hota-Mitchell S, Clarke MW, Podesta RB, Dekaban GA 1999. Recombinant vaccinia and gene gun vectors expressing the large subunit of Schistosoma mansoni calpain used in a murine immunization-challenge model. Vaccine 17: 13381354.

Jacobsen LV, S $\phi g a r d$ B, Riis A 2000. Pharmacokinetics and pharmacodynamics of a premixed formulation of soluble and protamine-retarded insulin aspart. Eur J Clin Pharmacol 56: 399403.

Jankovic D, Wynn TA, Kullberg MC, Hieny S, Caspar P, James S, Cheever AW, Sher A 1999. Optimal vaccination against Schistosoma mansoni requires the induction of both B celland IFN-g dependent effects mechanisms. J Immunol 162: 345-351.

Lanuti M, Kouri CEL, Force SD, Chang MY, Amin K, Xu K, Blair IA, Kaiser LR 1999. Use of protamine to augment adenovirus-mediated cancer gene therapy. Gene Ther 6: 16001610. 
Li Z, Li K, Tong S 1999. Nephelometric determination of micro amounts of nucleic acids with protamine sulphate. Analyst 124: 907-910.

McManus DP 2005. Prospects for development of a transmission blocking vaccine against Schistosoma japonicum. Parasite Immunol 27: 297-308.

Nascimento EJM, Leão IC, Pereira VRA, Gomes, YM, Chikhlikar P, August T, Marques E, Lucena-Silva N 2002. Protective immunity of single and multi-antigen DNA vaccines against schistosomiasis. Mem Inst Oswaldo Cruz 97: 105-109.

Pearce EJ, Caspar P, Gryzch JM, Lewis FA, Sher A 1991. Downregulation of Th1 cytokine production accompanies induction of Th2 responses by a helminth, Schistosoma mansoni. J Exper Med 173: 159-164.

Pearce EJ 2003. Progress towards a vaccine for schistosomiasis. Acta Trop 86: 309-313.

Raviprakash K, Porter KR, Kochel TJ, Ewing D, Simmons M, Phillips I, Murphy GS, Weiss WR, Hayes CG 2000. Dengue virus type 1 DNA vaccine induces protective immune response in rhesus macaques. J Gen Virol 81: 1659-1667.

Robinson HL 1999. DNA vaccines: basic mechanism and immune responses. Internl J Mol Med 4: 549-555.

Sauma SY, Tanaka TM, Strand M 1991. Selective of a glycosylphosphatidylinositol-anchored antigen from the surface of Schistosoma mansoni. Mol Biochem Parasitol 46: 73-80.

Siddiqui AA, Phillips T, Charest H, Podesta RB, Quinlin ML, Pinkston JR, Lloyd JD, Pompa J, Villalovos RM, Paz M 2003a. Enhancement of Sm-p80 (large subunit of calpain) induced protective immunity against Schistosoma mansoni through co-delivery of interleukin-2 and interleukin-12 in a DNA vaccine formulation. Vaccine 21:2882-2889.

Siddiqui AA, Phillips T, Charest H, Podesta RB, Quinlin ML, Pinkston JR, Lloyd JD, Paz M, Villalovos RM, Pompa J 2003 b. Induction of protective immunity against Schistosoma mansoni via DNA priming and boosting with the large sub- unit of calpain (Sm-p80): adjuvant effects of granulocytemacrophage colony-stimulating factor and interleukin-4. Infect Immun 71: 3844-3851.

Siddiqui AA, Pinkston JR, Quinlin ML, Kavikondala V, RewersFelkins KA, Phillips T, Pompa J 2005. Characterization of protective immunity induced against Schistosoma mansoni via DNA priming with the large subunit of calpain (Sm-p80) in the presence of genetic adjuvants. Parasite 12:3-8.

Shalaby KA, Yin L, Thakur A, Christen L, Niles EG, LoVerde PT 2003. Protection against Schistosoma mansoni utilizing DNA vaccination with genes encoding $\mathrm{Cu} / \mathrm{Zn}$ cytosolic superoxide dismutase, signal peptide-containing superoxide dismutase and glutathione peroxidase enzymes. Vaccine 22: 130-136.

Sorgi FL, Bhattacharya S, Huang L 1997. Protamine sulfate enhances lipid mediated gene transfer. Gene Ther 4: 961-968.

Waine GJ, Mazzer DR, McManus D.P 1999. DNA immunization by intramuscular injection or gene gun induces specific IgG antibodies against a Schistosoma japonicum $22 \mathrm{kDa}$ antigen, $\mathrm{Sj} 22$, when fused to the murine Ig k-chain secretory. Parasite Immunol 21: 53-56.

Welz C, Neuhuber W, Schreirer H, Repp R, Rascher W, Fahr A 2000. Nuclear gene targeting using negatively charged liposomes. Int J Pharm 196: 251-252.

Yang W, Waine GJ, McManus DP 1995. Antibodies to Schistosoma japonicum (asian bloodfluke) paramyosin induced by nucleic acid vaccination. Biochem Biophys Res Commun 212: 1029-1039.

You J, Kamihira M, Iijima S 1999. Enhancement of transfection efficiency by protamine in DDAB lipid vesicle-mediated gene transfer. J Biochem 125: 1160-1167.

Zhu Y, Si J, Harn DA, Xu M, Ren J, Yu C, Liang Y, Yin X, He W, Cao G 2006. Schistosoma japonicum triose-phosphate isomerase plasmid DNA vaccine protects pigs against challenge infection. Parasitology 132: 67-71. 